\title{
TOTAL QUALITY MANAGEMENT: PARADIGMA BARU MANAGEMEN PERGURUAN TINGGI DALAM MENGHADAPI PERSAINGAN KUALITAS PENDIDIKAN
}

\author{
Wariyanti \\ STBA CAHAYA SURYA KEDIRI \\ roro_wariyanti@gmail.com
}

Diterima 05 Januari 2017, direvisi 07 Januari 2017, diternitkan 28 Pebruari 2017

\begin{abstract}
College is one of the means to build community. Universities can also be regarded as the agent of change in society and even the world. Humans were expected today are capable of developing their potential throughout. Overview whole human beings has been defined in the law No. 20 of 2003 on the System Pendidian National Article 3 which states that the National Education aims at developing students' potentials in order to become a man of faith and fear of God Almighty, noble, healthy, knowledgeable, skilled, creative, independent, and become citizens of a democratic and accountable.

Based on these conditions, a University is a public institution undertaking the community to help to create students who have the expected quality.

With the demands of current conditions it is necessary seoramg leaders and members who have high performance in managing and running the educational process. While universities are expected are universities which have members who are always learning to achieve a change for the better in serving the community.
\end{abstract}

\section{PENDAHULUAN}

Era globalisasi saat ini menimbulkan kompetisi di berbagai bidang baik ekonomi, politik, budaya, sosial dan lain sebagainya. Kondisi seperti ini menuntut masyarakat untuk menyadari segala kemampuan yang dimilikinya agar mampu menghadapi tantangan tersebut. Sumbangan kemampuan dan kreatifitas merupakan salah satu faktor yang dapat merubah kehidupan masyarakat yang lebih baik. Oleh karena itu, saat ini yang diperlukan adalah bagaimana menciptakan kehidupan yang lebih baik melalui manusia yang berkualitas. Manusia yang berkualitas tersebut meliputi aspek fisik, mental maupun spiritual.

Pembangunan manusia (human development) yang saat ini selalu didengungkan merupakan suatu gagasan yang tidak hanya mengacu pada salah satu aspek saja akan tetapi harus membangun keseluruhan aspek sumber daya yang dimiliki oleh manusia. Jika hanya salah satu aspek saja yang menjadi fokus perhatian maka hal tersebut akan menimbulkan dampak negatif bagi kehidupan masyarakat itu sendiri.

Membahas mengenai kualitas sumber daya manusia, pendidikan memegang peran yang sangat penting dalam proses peningkatan kualitas sumber daya manusia. Peningkatan kualitas pendidikan merupakan suatu proses terintegrasi dengan proses peningkatan kualitas sumber daya manusia itu sendiri. Menyadari pentingnya proses peningkatan kualitas sumber daya manusia, maka pemerintah bersama 
kalangan swasta telah dan terus berupaya mewujudkan amanat tersebut melalui berbagai usaha pembangunan pendidikan yang lebih berkualitas antara lain melalui pengembangan dan perbaikan kurikulum dan sistem evaluasi, perbaikan sarana pendidikan, pengembangan dan pengadaan materi ajar, serta pelatihan bagi dosen dan tenaga pendidikan lainnya. Tetapi pada kenyataannya upaya pemerintah tersebut belum cukup berarti dalam meningkatkan kualitas pendidikan.

Universitas/PT merupakan salah satu sarana untuk membangun masyarakat. Perguruan Tinggi juga dapat dikatakan sebagai agen perubahan masyarakat bahkan dunia. Manusia yang diharapkan saat ini adalah manusia yang mampu mengembangkan keseluruh potensi yang dimilikinya. Gambaran manusia yang seutuhnya tersebut telah dirumuskan di dalam undang-undang RI Nomor 20 Tahun 2003 tentang Sistem Pendidian Nasional pasal 3 yang menyatakan bahwa Pendidikan Nasional bertujuan untuk berkembangnya potensi peserta didik agar menjadi manusia yang beriman dan bertakwa kepada Tuhan yang Maha Esa, berakhlak mulia, sehat, berilmu, cakap, kreatif, mandiri, dan menjadi warga negara yang demokratis serta bertanggung jawab.

Berlandaskan tujuan tersebut diharapkan pendidikan akan mampu menciptakan manusia yang mampu menghadapi tantangan dan perubahan secara positif. Perubahan yang terjadi di berbagai aspek merupakan kondisi yang menuntut masyarakat harus memiliki keunggulan dan daya saing, kepribadian tangguh dan positif, cerdas, kerja keras, sehat dan tidak mudah putus asa.

Berdasarkan hal tersebut maka Perguruan Tinggi sebagai lembaga masyarakat mengemban amanat masyarakat untuk membantu menciptakan mahasiswa yang memiliki kualitas yang diharapkan. Dengan tuntutan kondisi saat ini maka diperlukan seoramg pemimpin dan anggota yang memiliki kinerja tinggi dalam mengelola dan menjalankan proses pendidikan. Sedangkan Perguruan Tinggi yang diharapkan adalah Perguruan Tinggi yang memiliki anggota yang selalu belajar untuk mencapai suatu perubahan yang lebih baik dalam melayani masyarakat.

Marguardt (1996:15) mengemukakan bahwa perubahan yang bukan menjadi sekedar produk, aktivitas dan struktur eksternal yang yang dapat kita amati, tetapi juga perubahan internal yang terjadi dalam organisasi. Perubahan itu adalah mengenai nilai-nilai, cara berfikir, mind-set, strategi dan bahkan mungkin tujuan-tujuan yang akan dicapai.

Perguruan Tinggi harus terus menerus melakukan perbaikan secara berkelanjutan untuk lebih meningkatkan kualitas yang diharapkan sesuai dengan tuntutan dan perubahan. Perbaikan kualitas tersebut harus dimulai dari seorang pimpinan yaitu rektor yang bertanggung jawab atas penyelengaraan pendidikan di Perguruan Tinggi, walaupun pada hakekatnya setiap personil universitas memiliki tanggung jawab. Kualitas Perguruan Tinggi dapat dilihat salah satunya melalui hasil output yang berupa kelulusan dan IPK yang diperoleh.

Perguruan Tinggi merupakan salah satu program pendidikan formal yang melayani dan membantu mahasiswa untuk memiliki kecakapan atau skill tertentu sesuai dengan program yang ditawarkan. Dengan adanya kebijakan program ini diharapkan akan mampu menciptakan mahasiswa yang memiliki kemampuan dan kemandirian sehingga dapat mengatasi masalah yang selama ini masih menjadi dilema bagi negara ini yaitu mengatasi pengangguran dan ketergantungan terhadap negara lain.

Dalam artikel ini dilakukan analisis Perguruan Tinggi bermutu dan berbagai faktorfaktor yang mempengaruhinya, berdasarkan data hasil kelulusan dan masih banyaknya tingkat pengangguran pasca lulus maka 
beberapa hal yang masih perlu mendapat perhatian dalam peningkatan kualitas Perguruan Tinggi adalah:

1. Pendidikan selama ini bersifat input oriented.

2. Pengelolaan pendidikan selama ini bersifat macro-oriented, diatur oleh jajaran birokrasi ditingkat pusat. Akibatnya, banyak faktor yang diproyeksikan ditingkat makro (pusat) tidak terjadi atau tidak berjalan sebagaimana mestinya di tingkat mikro (Perguruan Tinggi).

3. Masih terbatasnya komitmen masyarakat Perguruan Tinggi (rektor, dosen, orang tua, mahasiswa, tokoh masyarakat dan pejabat setempat) terhadap penyelengaraan pendidikan di Perguruan Tinggi.

4. Masih terbatasnya kemitraan Perguruan Tinggi dengan dunia industri baik lokal regional maupun internasional.

5. Masih terbatasnya kesadaran masyarakat untuk mendukung program kebijakan Perguruan Tinggi.

Bertolak dari latar belakang yang telah diungkapkan di atas, maka fokus artikel ini didasari oleh beberapa permasalahan yang muncul dalam managemen Perguruan Tinggi yang terjadi saat ini. Ada beberapa kesenjangan (gap) antara managemen Perguruan Tinggi bermutu secara teoritik dengan kondisi nyata khususnya di Perguruan Tinggi. Berdasarkan hasil observasi dan wawancara maka penulis menyimpulkan beberapa masalah atau kesenjangan (gap) terjadi adalah sebagai berikut.

1. Pelaksanaan manajemen Perguruan Tinggi lebih mengarah pada orientasi input, yaitu lebih menekankan bagaimana cara agar Perguruan Tinggi memiliki mahasiswa yang banyak sehingga bisa bertahan dalam kapasitas kuantitas bukan kualitas. Hal ini pada akhirnya berdampak pada kelemahan dalam proses pelayanan dan output yang di hasilkan.

2. Kurang melibatkan masyarakat setempat untuk memberdayakan sumber daya yang ada di sekeliling Perguruan Tinggi.

3. Komitmen rektor sebagai pimpinan perlu terus dibangun kembali.

4. Kerjasama (teamwork) antara rektor, personil dan stakeholders masih perlu di tingkatkan.

5. Belum seutuhnya memiliki prinsip bahwa mahasiswa adalah pelanggan yang harus dilayani sebaik-baiknya.

6. Komunikasi antara rektor dan staf yang kurang efektif.

7. Belum memiliki prinsip perbaikan secara terus menerus dalam melayani mahasiswa.

8. Pengukuran yang belum jelas terhadap keberhasilan lulusan, yang salah satunya di tandai dengan tidak semua Perguruan Tinggi memiliki data atau grafik penyeraan lulusan dalam dunia industri atau dunia kerja baik secara kelompok atau mandiri.

9. Penyusunan basis data dan profil Perguruan Tinggi belum presentatif, akurat, valid dan secara sistematis menyangkut berbagai aspek akademis, administratif (mahasiswa, dosen, staf) dan keuangan.

\section{PARADIGMA BARU MANAJEMEN PERGURUAN TINGGI}

Lingkungan statejik universitas, baik Perguruan Tinggi yang berorientasi profit maupun non profit, senantiasa mengalami perubahan yang dinamis dan terus menerus tumbuh berkembang. Peluang dan ancaman yang berada di lingkungan eksternal (external environment), akan mempengaruhi lingkungan 
internal Perguruan Tinggi (internal environment), baik berupa kekuatan maupun kelemahan yang ada dalam universitas. Perubahan baik terjadi pada lingkungan internal maupun eksternal ini, menuntut kepiawaian para penyelengara/pendiri Perguruan Tinggi untuk bisa menyikapi dan mengantisipasinya, manakala menginginkan Perguruan Tinggi tetap eksis atau bahkan menjadi universitas yang secara terus-menerus berkembang. Perguruan Tinggi harus cepat tanggap terhadap berbagai perubahan yang cepat yang dihadapinya dalam bentuk kebijakan-kebijakan yang tepat. Perguruan Tinggi yang tidak mau berubah sesuai dengan tuntutan zaman akan mati seperti layaknya dinosaurus yang lamban dan digilas zaman.

Perguruan Tingi terdiri dari berbagai unsur sumber daya yang harus dikelola dan dimanfaatkan dengan baik demi tercapainya tujuan Perguruan Tinggi. Diantara unsur-unsur Perguruan Tinggi yang terdiri dari mahasiswa, kampus, akademik, metode kerja, pembiayaan dll, sumber daya manusia merupakan unsur yang paling dinamis dan kompleks karena pengelolaan Perguruan Tinggi pada dasarnya merupakan proses pengeloaan manusia dengan perbedaan sifat-sifat individual yang dimilikinya. Claman (1998) mengatakan bahawa sumber daya manusia tidak lagi dipandang sebagai komponen yang dapat dengan begitu saja diganti dengan koponen yang lain. Ditegaskan pula bahwa era ekonomi berbasis pengetahuan sebagaimana yang berkembang dewasa ini, sama sekali tidak tepat bila memandang sumber daya manusia sekedar a cost of doing business. Karenanya menurut Kotter dan Heskett (1992), dan Waterman (1994) sumber daya manusia harus didahulukan. Hal tersebut sesuai dengan paradigma baru yang mengidentifikasikan bahwa sumber daya manusia merupakan aset terpenting, walaupun untuk mendapatkan dan mempertahankan aset tersebut memerlukan dukungan dana yang tidak sedikit.

Tetapi kenyataan yang dihadapi oleh Perguruan Tinggi adalah adanya ketidak seimbangan antara pertumbuhan kuantitas dan perkembangan kualitas. Kenyataan ini memberikan gambaran bahwa para akademisi yang menduduki posisi kunci pada Perguruan Tinggi yaitu rektor umumnya kurang peduli terhadap perkembangan ilmu manajemen pendidikan atau belum memadainya pemahaman dan pengetahuan mengenai manajemenyang menjalani bahwa kelancaran organisasi diukur dengan kepatuhan pihak bawahan kepada atasan, bukan suatu strategi yang berfokus pada perkembangan ilmu pengetahuan. Hal ini dapat memberikan gambaran juga terhadap budaya kerja yang kurang akseleratif sehingga perubahan yang dilakukan tidak seimbang dengan perolehan mutu yang dituntut oleh persaingan domestik maupun global.

Kondisi objektif tersebut juga mempunyai arti bahwa manajemen yang selama ini digunakan belum memperoleh hasilyang optimal, demikian juga strategi yang digunakan belum mampu menyelesaikan masalah yang mendesak dengan tingkat kompleksifitas.

Tantangan yang dihadapi dan hasil yang diharapkan cukup tinggi, untuk itulah diperlukan jalan keluar yang memungkinkan Perguruan Tinggi lebih berkemampuan mengatasi berbagai masalah tersebut. Jalan keluar atau solusi yang dimaksud adalah penerapan Total Quality Management (TQM). TQM berguna untuk menetapkan arah masa depan organisasi dan mengimplemantasikan keputusan yang bertujuan untuk mencapai sasaran jangka panjang dan jangka pendek suatu Perguruan Tinggi. 
IMPLEMENTASI TOTAL QUALITY MANAGEMENT DI PERGURUAN TINGGI

Perguruan Tinggi merupakan pendidikan yang berorientasi pada skill dan moral yang diharapkan mampu tepat guna dan produktif di kehidupan nyata. Oleh karenaitu, kemitraan dengan masyarakat merupakan langkah awal untuk terjalinnya hubungan yang harmonis antara lembaga pendidikan dengan masyarakat. Dengan menjalin kemitraan maka secara otomatis akan terbentuk kerjasama dan keterlibatan baik mental maupun emosional antara masyarakat dengan pihak Perguruan Tinggi.

Seorang pimpinan atau dalam hal ini rektor harus memiliki kemampuan untuk menjalankan tugas manajerialnya. Oleh karena itu, seorang rektor harus memiliki gaya kepemimpinan yang ideal, kompetensi dan komitmen yang kuat sebagai salah satu kunci keberhasilan dalam memimpin sebuah organisasi dalam mencapai mutu yang baik.

Perguruan Tinggi bermutu/berkualitas akan terwujud dengan dengan baik jika seorang rektor dan para personil Perguruan Tinggi memiliki kompetensi yang diwujudkan melalui kinerja yang baik. Seluruh sumber daya yang dimiliki oleh seseorang baik berupa motivasi, konsep diri, kemampuan atau skill dan karakteristik atau kepribadian (traits) semuanya itu merupakan kapasitas diri atau modal dasar yang mendukung terwujudnya keberhasilan seseorang dalam menjalankan fungsi dan tugasnya.

Seseorang pemimpin harus mampu menciptakan sebuah lembaga publik yang mampu melayani pelanggan dalam hal ini masyarakatPerguruan Tinggi. Managemen mutu merupakan suatu upaya yang dapat dilakukan oleh pemimpin untuk mencapai tujuan. Melalui kemampuan managerialnya dan unjuk kerja dalam melayani para pelanggan yaitu mahasiswa, orang tua mahasiswa, dan masyarakat.

Konsep mutu sebagai konsep yang relatif bukan konsep yang absolute., sehingga mutu memiliki dua aspek yaitu memenuhi spesifikasi dan memenuhi persyaratan-persyaratan yang di tuntut oleh konsumen.

Berdasarkan hal tersebut, maka Perguruan Tinggi yang bermutu adalah Perguruan Tinggi yang memiliki kepemimpinan yang tepat dengan melaksanakan keseluruhan unsur determinan terhadap kualitas yang diharapkan. Perguruan Tinggi bermutu juga dapat dilihat sejauh mana iklim/kondisi Perguruan Tinggi memberikan kontribusi positif terhadap terwujudnya Perguruan Tinggi bermutu/berkualitas. Kemudian sejauh mana rektor mampu mendorong para personil Perguruan Tinggi untuk dapat memberikan kontribusi positif terhadap terwujudnya Total Quality Managemen di Perguruan Tinggi.

Dengan permasalahan diatas maka penulis memberikan solusi dengan implementasi Total Quality Management (TQM) untuk meningkatkan kualitas Perguruan Tinggi dalam menghadapi persaingan antara Perguruan Tinggi.

Dalam mengimplementasikan TQM di Perguruan Tinggi, rektor memegang peranan penting dalam upaya mendorong setiap anggota atau personil Perguruan Tinggi untuk ikut berperan dan berkontribusi dalam perbaikan kualitas. Melalui gaya atau perilakunya diharapkan rektor dapat secara efektif melaksanakan TQM, TQM dalam sebuah organisasi berarti mengadakan perubahan mendasar dalam organisasi, yang meliputi perubahan kultural dan perubahan substantif dalam managemen.

Ada dua faktor yang dapat menjelaskan mengapa upaya perbaikan mutu pendidikan selama ini kurang atau tidak berhasil. Pertama, Strategi yang demikian lebih bersandar kepada asumsi bahwabilamana semuainput pendidikan 
telah dpenuhi, seperti penyediaan buku-buku (materi ajar) dan alat belajar lainnya, penyediaan sarana pendidikan, pelatihan dosen dan tenaga kependidikan lainnya, maka secara otomatis lembaga pendidikan (Perguruan Tinggi) akan dapat menghasilkan output (keluaran) yang bermutu sebagaimana yang diharapkan. Ternyata strategi input-output yang diperkenalkan oleh teori education production function (Hanushek, 1979, 1981) tidak berfungsi sepenuhnya di lembaga pendidikan (Perguruan Tinggi) melainkan hanya terjadi dalam institusi ekonomi dan industri.

Kedua, pengelolaan pendidikan selama ini lebih bersifat macro-oriented, diatur oleh jajaran birokrasi ditingkat pusat. Akibatnya, banyak faktor yang diproyeksikan ditingkat makro (pusat) tidak terjadi atau tidak berjalan sebagaimana mestinya ditingkat mikro (Perguruan Tinggi). Atau dengan singkat dapat dikatakan bahwa kompleksitasnya cakupan permasalahan pendidikan, seringkali tidak dapat terpikirkan secara utuh dan akurat oleh birokrasi pusat.

Diskusi tersebut memberikan pemahaman kepada kita bahwa pembangunan pendidikan bukan hanya berfokus pada penyediaan faktor input pendidikan tetapi juga harus lebih memperhatikan faktor proses pendidikan. Input pendidikan merupakan hal yang mutlak harus ada dalam batas-batas tertentu tetapi tidak menjadi jaminan dapat secara otomatis meninkatkan mutu pendidikan. Disamping itu mengingat Perguruan Tinggi sebagai unit pelaksana pendidikan formal terdepan dengan berbagai keragaman potensi mahasiswa yang memerlukan layanan pendidikan yang beragam, kondisi lingkungan yang berbeda satu dengan yang lainnya, maka Perguruan Tinggi harus dinamis dan kreatif dalam melaksanakan perannya untuk mengupayakan peningkatan kualitas/mutu pendidikan, hal ini akan dapat dilaksanakan jika Perguruan Tinggi dengan berbagai keragamannya itu, diberikan kepercayaan untuk mengatur dan mengurus dirinya sendiri dengan kondisi lingkungan dan kebutuhan mahasiswanya.

Walaupun demikian, agar mutu tetap terjaga dan agar proses peningkatan mutu tetap terkontrol, maka harus ada standar yang diatur dan disepakati secara nasional untuk dijadikan indikator evaluasi keberhasilan peningkatan mutu tersebut (adanya branchmarking). Pemikiran ini telah mendorong munculnya pendekatan baru, yakni pengelolaan peningkatan mutu pendidikan dimasa mendatang, memandang universitas harus berbasis mutu sebagai institusi paling depan dalam kegiatan pendidikan.

Mutu merupakan derajat keunggulan sebuah produk atau pelayanan jasa. Sebuah produk yang bersaing dengan produk lainnya atau suatu pelayanan jasa bersaing dengan pelayanan jasa lainnya memiliki tingkat keunggulan relatif, produk atau pelayanan jasa yang lebih unggul adalah produk atau pelayanan jasa yang bermutu. Mutu adalah sesuatu kesempatan untuk menempatkan pada posisi kompetitif. Bagi produsen atau penyedia jasa, kesempatan untuk berkompetisi merupakan hal sangat berharga, karena munculnya kompetitor baru baginya merupakan sebuah wahana untuk meningkatkan mutu produk atau layanan jasa. Mutu adalah: Fitness for use, meeting customer expectations, conformance to costemer satisfaction. Mutu pada dasarnya merupakan penyesuaian manfaat atau kegunaan. Artinya harapan sesuai dengan kepuasan pemakai.

Kepemimpinan memiliki peran yang sangat strategis dalam melakukan pelayanan terhadap pendidikan. Krajewsky (1983:23) mengemukakan bahwa "Principle are the key to quality in the school and must be catalyst when its comen to the quality of education programs". Dengan demikian kemampuan seseorang pemimpin an gaya kepemimpinan yang di terapkan sangat berpengaruh terhadap kinerja sebuah lembaga.

Kepemimpinan yang berorientasi pada 
tugas (initating structure) dan bawahan (consideration) merupakan suatu proses dimana seorang pemimpin tidak hanya memperhatikan faktor-faktor kebutuhan pemenuhan tugas dan target yang telah di tentukan tetapi juga memperhatikan faktor moral dan manusiawi dari para anggotanya. Hal ini sejalan dengan gaya kepemimpinan transformasional yang merupakan proses dimana seorang pemimpin menaikkan moral dan memotivasi bawahan ke tingkat yang lebih tinggi. Artinya pemimpin berusaha menaikkan kesadaran bawahan, dengan mendorong idealisme dan nilai moral ke tingkat yang lebih tinggi, seperti yang terkait dengan kebebasan,keadilan kedamaian, keseimbangan dan kemanusiaan, serta bukan berdasarkan emosional seperti rasa ketakutan, ketamakan, kecemburuan atau kebencian (Burn, 1978).

Kinerja seseorang dapat dipengaruhi oleh beberapa faktor diantaranya lingkungan. Castetter $(1981 ; 281)$ berpendapat bahwa secara umum terdapat tiga sumber utama yang mempengaruhi efektif tidaknya kinerja seseorang yaitu: faktor individu, faktor organisasi dan faktor lingkungan yang di dalamnya termasuk iklim organisasi. Untuk mencapai peningkatan kualitas kampus secara berkelanjutan, di perlukan faktor pendukung yang berpengaruh baik secara langsung atau tidak langsung.

Di universitas yang bersangkutan, sebagaimana ungkapan dari Deming (1988) bahwa "Quality is made in the board room not on the factory floor". Ungkapan tersebut mengisyaratkan bahwa implementasi TQM membutuhkan transformasi kultural yang hanya dapat dimulai dari pimpinan puncak. Kebersihan menerapkan TQM merupakan prestasi bagi rektor. Dengan demikian kinerja rektor dapat dapat di nilai dari sejauh mana rektor mampu mengimplementasikan TQM di Perguruan Tinggi yang dipimpinnya.

Berdasarkan kajian terhadap berbagai konsep artikel ini, bahwa untuk Perguruan
Tinggi bermutu/berkualitas di pengaruhi oleh berbagai faktor diantaranya; kepemimpinan, kondisi Perguruan Tinggi dan implementasi TQM. Keseluruhan faktor independent tersebut jika diimplementasikan didalam suatu Perguruan Tinggi maka akan memberikan kontribusi dan menghasilkan suatu gambaran sejauh mana kinerja rektor mampu memberikan kontribusi dan selanjutnya bagi terciptanya Perguruan Tinggi bermutu/bermutu.

Perilaku kepemimpinan saat ini dirasakan sudah cukup baik namun ada hal-hal yang perlu ditingkatkan, misalnya kerjasama antar dan berbagai PT yang terkenal baik di Indonesia, Asia, Australia maupun Amerika. Iklim organisasi yang kondusif sangat dibutuhkan dalam proses peningkatan mutu pendidikan namun, saat ini iklim organisasi masih menuggu perintah pimpinan dan kurang adanya inovasi dan kreativitas.

Dengan manajemen universitas bermutu di harapkan seluruh sumber daya baik secara material maupun sumber daya manusia di Universitas secara optimal mampu memberikan pelayanan bagi para mahasiswa agar dapat mewujudkan dan meningkatkan kualitas lulusan. Lulusan yang berkualitas tidah hanya dilihat dari hasil nilai IPK saja, akan tetapi jika dilihat sejauh mana lulusan tersebut dapat mandiri dan diterima oleh dunia industri atau dunia usaha. Hal yang tidak kalah penting dalam menciptakan Perguruan Tinggi bermutu adalah dukungan pemerintah sebagai regulator melalui berbagai kebijakan dan masyarakat yaitu melalui dunia kerja atau industri serta organisasi profesi.

Artikel ini di harapkan menghasilkan model strategi yang dapat menjadi suatu alternatif sebagai upaya untuk menciptakan Perguruan Tinggi bermutu dan mampu menjawab berbagai masalah yang sebenarnya sedang dihadapi. Agar dapat memahami secara operasional tentang strategi yang di hasilkan dari penelitian ini maka melalui implikasi dan rekomendasi diharapkan juga dapat memberikan kontribusi 
positif terhadap perkembangan wawasan bagi praktisi pendidikan dan seluruh stakeholders sekaligus sebagai wahana untuk perkembangan secara keilmuan khususnya dalam ilmu managemen pendidikan.

\section{KESIMPULAN}

Perguruan Tinggi merupakan salah satu sarana untuk membangun masyarakat. Perguruan Tinggi juga dapat dikatakan sebagai agen perubahan masyarakat bahkan dunia. Berdasarkan hal tersebut maka Perguruan Tinggi sebagai lembaga masyarakat mengemban amanat masyarakat untuk membantu menciptakan mahasiswa yang memiliki kualitas yang diharapkan.

Perguruan Tinggi yang bermutu adalah Pergruruan Tinggi yang memiliki kepemimpinan yang tepat dengan melaksanakan keseluruhan unsur determinan terhadap kualitas yang diharapkan. Perguruan Tinggi bermutu juga dapat dilihat sejauh mana iklim/kondisi Perguruan Tinggi memberikan kontribusi positif terhadap terwujudnya Perguruan Tinggi bermutu/berkualitas. Kemudian sejauh mana rektor mampu mendorong para personil Perguruan Tinggi untuk dapat memberikan kontribusi positif terhadap terwujudnya Total Quality Managemen di Perguruan Tinggi.

Dalam mengimplementasikan TQM di Perguruan Tinggi, rektor memegang peranan penting dalam upaya mendorong setiap anggota atau personil Perguruan Tinggi untuk ikut berperan dan berkontribusi dalam perbaikan kualitas. Melalui gaya atau perilakunya diharapkan rektor dapat secara efektif melaksanakan TQM, TQM dalam sebuah organisasi berarti mengadakan perubahan mendasar dalam organisasi, yang meliputi perubahan kultural dan perubahan substantif dalam manajemen. Berdasarkan kajian terhadap berbagai konsep artikel ini bahwa untuk Perguruan Tinggi bermutu/berkualitas di pengaruhi oleh berbagai faktor diantaranya; kepemimpinan, kondisi universitas dan implementasi TQM. Keseluruhan faktor independent tersebut jika diimplementasikan didalam suatu Perguruan Tinggi maka akan memberikan kontribusi dan menghasilkan suatu gambaran sejauh mana kinerja rektor mampu memberikan kontribusi dan selanjutnya bagi terciptanya Perguruan Tinggi bermutu/ berkualitas.

Perilaku kepemimpinan saat ini dirasakan sudah cukup baik namun ada hal-hal yang perlu ditingkatkan, misalnya kerjasama antar dan berbagai PT yang terkenal baik di Indonesia, Asia, Australia maupun Amerika. Iklim organisasi yang kondusif sangat dibutuhkan dalam proses peningkatan mutu pendidikan namun, saat ini iklim organisasi masih menuggu perintah pimpinan dan kurang adanya inovasi dan kreativitas.

Dengan TQM di harapkan seluruh sumber daya baik secara material maupun sumber daya manusia di Perguruan Tinggi secara optimal mampu memberikan pelayanan bagi para mahasiswa agar dapat mewujudkan dan meningkatkan kualitas lulusan. Lulusan yang berkualitas tidah hanya dilihat dari hasil nilai IPK saja, akan tetapi jika dilihat sejauh mana lulusan tersebut dapat mandiri dan diterima oleh dunia industri atau dunia usaha. Hal yang tidak kalah penting dalam menciptakan Perguruan Tinggi bermutu adalah dukungan pemerintah sebagai regulator melalui berbagai kebijakan dan masyarakat yaitu melalui dunia kerja atau industri serta organisasi profesi.

\section{DAFTAR PUSTAKA}

\section{Baron, et al. (1998). Exploring the culture of teaching and learning: A community research project. Research Report.}

Castetter, William, A. (1981). The Personil Function in Educational Administration. New York: MacMillan Publishing Co. 
Claman, Priscilla H. 1998. Work Has Changed but Our Compensation Program Have Not. Compensation and Benefits Management, Winter.

Davis and Newstrom. (1995). Human Behaviour at Work; Organizational Behavior. $7^{\text {th }}$ ed, Mc Graw: Hill Publishing Company.

Deming, W. E. (1998). Out of Crisis. Cambridge: Massachussetts Institute of Technology.

Juran, Josep and Grynn. FM (1989). Politic and Objective, Quality Planning and Analysis. Mc Graw Hill.

Juran, M., J. (1995). Merancang Mutu, Buku 5, Jakarta: PT. Pustaka Binawan Presindo.

Kotler, John P. (1997). Leading Change. Jakarta: Gramedia Pustaka Utama.

Kotler (1997). Marketing Management: Analysis, Planning, Implementation, and Control, 9th ed. Englewood Cliffs, $\mathrm{N}, \mathrm{J}$; Prentice Hall International, Inc.

Luthans, Sweeney dan McFarlin (2002), Organizational Behaviour, Singapore: McGraw-Hill International.
Marguardt (1996). Building the Learning Organization. New York: McGraw- Hill.

Riduwan dan Akton. (2006). Rumus dan Data dalam Aplikasi Statistik. Bandung:Alfabeta.

Robbins P. Stephen (2001). Perilaku Organisasi. Jakarta: PT. Prenhalllindo.

Sallis Edward (1993). Total Quality Management in Education. London: Kogan.

Spencer \& Spencer (1993). Competence at Work Models Supperior Performance, John Willey \& SMS, Inc, New York: A Division of Mac Miller Publishing, Co.,Inc.

Tjiptono Fandy (1996). Total Quality Management. Edisi II. Yogyakarta: PenerbitAndi.

Undang-undang nomor 20 Tahun 2003 tentang Sistem Pendidikan. Jakarta: Sinar Grafika.

Yuki, Gary. (1996). Leadership in Organization (Terjemahan). Edisi KeTiga, Jakarta: PT. Buana Ilmu Popular. 